\title{
Pharmacological Effect of Nandrolone Phenylpropionate on the Healing of Dental Extraction Wounds: A Histological Investigation in Rats
}

\author{
by \\ Ruy dos SANTOS-PINTO,* Tetuo OKAMOTO* and \\ Acyr Lima de CASTRO* \\ Introduction
}

The distinct stages of the wound healing following teeth extraction were established through several clinic[1], radiographic[2, 3, 4, 5, 6] and histological[7, 2, 3, 8, $4,9,10]$ studies.

It is recognized, however, that metabolic changes take place during and after surgical procedures, which must be studied in connection with healing processes.

The anabolic steroids because of their effect have been experimentally used following fractures[11] as well as for the healing of soft tissues[12] with promising results.

LASSILA and STAUfFER[13], did not verify any significant influence of anabolic steroids on the healing of teeth extraction wounds.

For this reason, the purpose of this paper is to verify the anabolic steroid effects, following nandrolone phenylpropionate administration, at the different stages of teeth extraction wounds.

\section{Material and Method}

For the present study, we used forty-eight male albino rats (Rattus norvegicus, Wistar strain) weighing about 100 grams each.

Before and during the entire experimental period, the animals received standard food and water ad libitum, except for 24 hours after tooth extractions when solid food was discontinued.

The right upper incisors were extracted and the mucous membrane sutured with 5-0 mononylon. For this procedure, the animals were anesthetized with sulphuric ether. For observational purposes, the animals were divided into two groups: control and experimental.

In the first group, each animal was injected with $0.5 \mathrm{ml}$ of almond oil; in the second group, each one received in $0.5 \mathrm{ml}$ of almond oil $1 \mathrm{mg}$ of nandrolone phenylpropionate. $\uparrow$ These injections were administered intraperiotoneally on a daily basis.

Four animals were killed after postoperative periods of 2, 4, 8, 12, 16 and 20 days. After each rat was put to death, the anatomical pieces could be obtained. These

* Dept. of Oral Surgery, Faculdade de Odontologia de Araçatuba, Araçatuba, São Paulo, Brasil. $\uparrow$ Durabolin, Organon. 
were placed in 10 per cent formalin and, after fixation, decalcified in a formic acidsodium citrate solution[14]. After this, they were embedded in paraffin for 15 minutes in vacuum. The blocks thus obtained were cut by a rotary microtome into serial sections 6 microns thick. The tissues were subsequently stained with hematoxylin and eosin for morphologic study.

\section{Results}

The results obtained after the respective passage of post-operative days are comparatively given in Table 1.

Table 1. The healing process following incisors extraction

\begin{tabular}{|c|c|c|}
\hline \multirow{2}{*}{$\begin{array}{l}\text { Postopera- } \\
\text { tive day }\end{array}$} & \multicolumn{2}{|c|}{ Animal } \\
\hline & Control & Experimental \\
\hline 2 & $\begin{array}{l}\text { Some young fibroblasts and newly } \\
\text { formed capillaries (Fig. 1). Great } \\
\text { number of macrophages and some } \\
\text { polymorphonuclear neutrophils. } \\
\text { Alveolar crest with some resorption. }\end{array}$ & $\begin{array}{l}\text { Great number of young fibroblasts } \\
\text { and numerous newly formed capil- } \\
\text { laries near the cortical alveolar bone } \\
\text { (Fig. 2) in three alveoli. Great } \\
\text { number of macrophages and some } \\
\text { polymorphonuclear neutrophils. } \\
\text { Alveolar crest with some resorption. }\end{array}$ \\
\hline 4 & $\begin{array}{l}\text { Great number of fibroblasts and } \\
\text { newly formed capillaries (Fig. 3). } \\
\text { Macrophages and some poly- } \\
\text { morphonuclear neutrophils. Alveolar } \\
\text { crest with resorption. }\end{array}$ & $\begin{array}{l}\text { Medial and apical third filled by } \\
\text { well vascularized connective tissue } \\
\text { and numerous fibroblasts (Fig. 4). } \\
\text { Alveolar crest with resorption. }\end{array}$ \\
\hline 8 & $\begin{array}{l}\text { Alveolus practically filled by well } \\
\text { vascularized connective tissue and } \\
\text { numerous fibroblasts. Some osseous } \\
\text { trabeculae (Fig. 5). Some lympho- } \\
\text { cytes, plasma cells and great number } \\
\text { of macrophages. }\end{array}$ & $\begin{array}{l}\text { Numerous osseous trabeculae } \\
\text { throughout the alveolus (Fig. 6). } \\
\text { Alveolar crest remodeled. The con- } \\
\text { nective tissue between osseous } \\
\text { trabeculae with few fibroblasts. }\end{array}$ \\
\hline 12 & $\begin{array}{l}\text { Thin osseous trabeculae throughout } \\
\text { the alveolus (Fig. 7). Between these } \\
\text { trabeculae there is a well vascularized } \\
\text { connective tissue. Alveolar crest } \\
\text { remodeled. }\end{array}$ & $\begin{array}{l}\text { Thicker and more regularly dis- } \\
\text { tributed trabeculae throughout the } \\
\text { alveolus when contrasted with the } \\
\text { anterior stage (Fig. 8). }\end{array}$ \\
\hline 16 & $\begin{array}{l}\text { Thicker osseous trabeculae than } \\
\text { those of } 12 \text { days fulfil the alveolus } \\
\text { (Fig. 9). Some areas with thin } \\
\text { osseous trabeculae. }\end{array}$ & $\begin{array}{l}\text { Alveolus entirely fulfilled by thick } \\
\text { osseous trabeculae. Few osteoblasts. } \\
\text { (Fig. 10). }\end{array}$ \\
\hline 20 & $\begin{array}{l}\text { Alveolus entirely fulfilled by newly } \\
\text { formed bone. Few osteoblasts. }\end{array}$ & $\begin{array}{l}\text { Alveolus entirely fulfilled by thick } \\
\text { osseous trabeculae. Few osteoblasts. }\end{array}$ \\
\hline
\end{tabular}

\section{Discussion}

Following an injury inflicted on the soft and hard tissues, there is an increase in 



Fig. 1 Control. Young fibroblasts and newly formed capillaries at the apical third. (Hematoxylin and eosin stain, $\times 100)$

Fig. 2 Experimental. Great number of young fibroblasts and numerous newly formed capillaries at the apical third. (Hematoxylin and eosin stain, $\times 100$ ).

Fig. 3 Control. Great number of fibroblasts and newly formed capillaries at the medial third. (Hematoxylin and eosin stain, $\times 100$ ).

Fig. 4 Experimental. A well vascularized connective tissue and numerous fibroblasts at the medial third. (Hematoxylin and eosin stain, $\times 100$ ).

Fig. 5 Control. Few osseous trabeculae at the apical third. (Hematoxylin and eosin stain, $\times 100$ ).

Fig. 6 Experimental. Numerous osseous trabeculae at the apical third. (Hematoxylin and eosin stain, $\times 100$ ). 

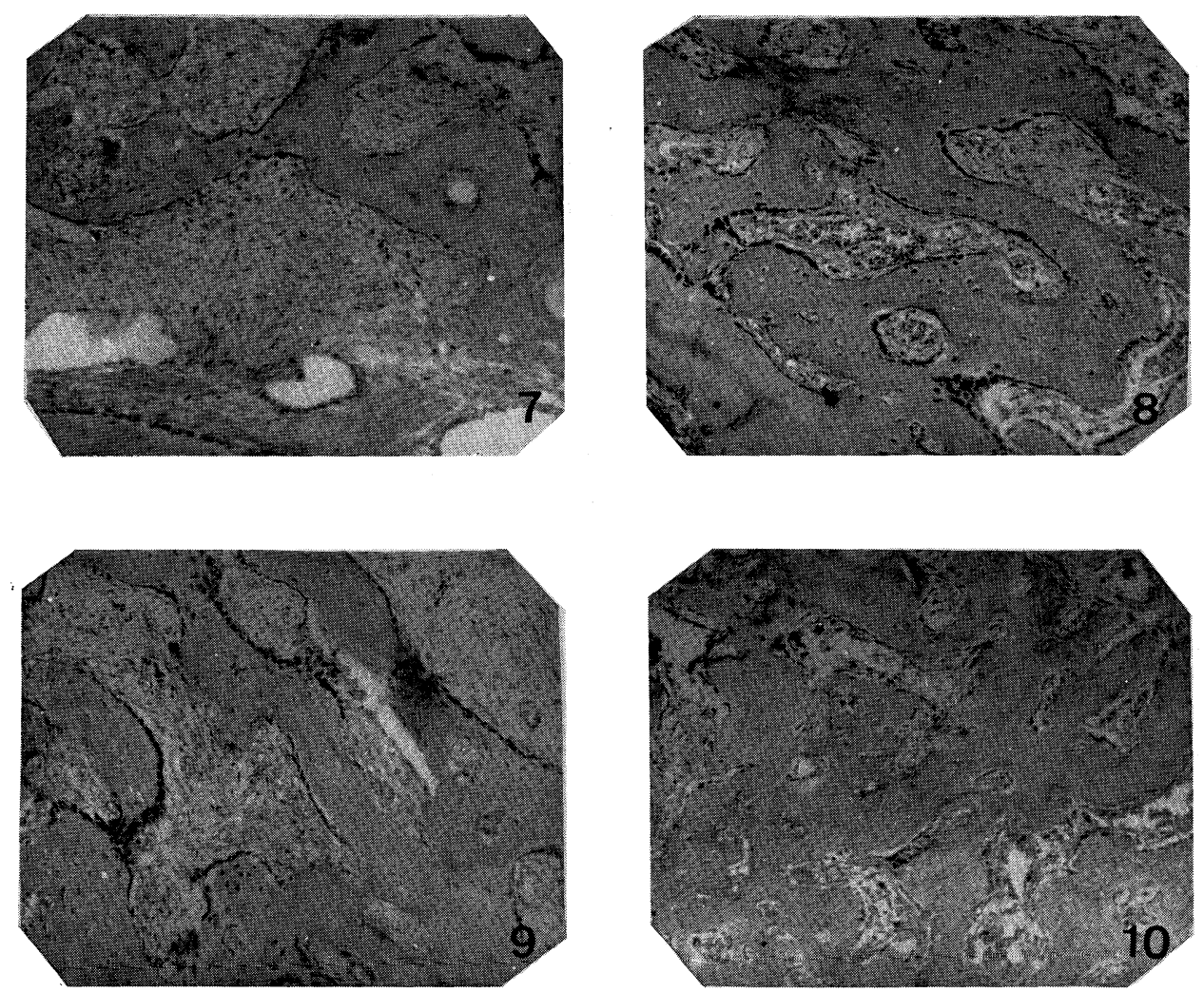

Fig. 7 Control. Thin osseous trabeculae (Medial third). (Hematoxylin and eosin stain, $\times 100$ ).

Fig. 8 Experimental. Thick osseous trabeculae (Medial third). (Hematoxylin and eosin stain, $\times 100$ ). Fig. 9 Control. Thick osseous trabeculae (Medial third). (Hematoxylin and eosin, $\times 100$ ).

Fig. 10 Experimental. Thick osseous trabeculae (Cervical third). (Hematoxylin and eosin, $\times 100$ ).

proteinic catabolism, disturbing the nitrogen balance. The anabolic steroids have been employed to increase the proteinic anabolism and balance the nitrogen retention.

In anabolic steroids treated animals, SINGH and UDUPA[11] verified a repair acceleration in osseous fractures. However, LASSILA and STAUFFER[13] did not verify such increasing action in the healing of tooth extraction wound.

In the present work, the repair occurred more rapidly in experimental animals. This fact could be established by major fibroblasts, newly formed capillaries and ground substance quantity at 2 postoperative days.

Since the acid mucopolysaccharides synthesis is often directly proportional to the fibroblast quantity, we can assume that in the subsequent postoperative stages the healing of extraction wound would increase in the experimental animals.

This hypothesis is based upon the anabolic steroids which play a favorable role in the acid mucopolysaccharides synthesis[11, 12].

It is supposed that the major and more rapidly organic matrix calcification results 
from the combination of calcium with the chondroitin sulphate of the ground substance or collagen fibers[15].

This assumption is corroborated by the fact that a rapider recovery takes place in experimental animals than in the controls.

\section{Conclusion}

The nandrolone phenylpropionate administration, following rat incisors extraction, accelerates the wound healing.

\section{References}

[1] DEEBDCH, R. F.: Healing process following the removal of teeth where injury greater than sustained in simple extraction is involved. Thesis. Northwestern University Dental School, 1934.

[2] Mangos, J. F.: The healing of extraction wounds. An experimental study based on microscopic and radiographic investigations, N. Z. dent. J. 37: 4, 1941.

[3] Huebsch, R. F., Coleman, R. D., Frandsen, A. M. and Becks, H.: The healing process following molar extraction. I. Normal male rats (Long-evans strain), Oral Surg., oral Med., and oral Path. 5: 864, 1952.

[4] Amler, M. H., Johnson, P. L. and Salman, I.: Histological and histochemical investigations of human alveolar socket healing in undisturbed extraction wounds, J. Am. dent. Ass. 61: 32, 1960.

[5] Dalitz, G. D.: A radiographic study of the rate at which human extraction wounds heal, Austr. Dent. J. 9: 466, 1964.

[6] Santos-Pinto, R.: Mineralização no processo de reparo em feridas de extração dental em cães. Estudo radiográfico e microscópico. Tese Livre Docência. Faculdade de Odontologia de Araçatuba, 1964.

[7] Euler, H.: Die Heilung von Extraktionswunden, Deutsche Monatschr. Zahnh. 41: 685, 1923.

[8] Hairstone, M. A.: Structural cytology of the healing wound. I. The fibroblast, Oral Surg., oral Med., and oral Path. 12: 1484, 1959.

[9] Amler, M. H., Salman, I., and Bungener, H.: Reticular and collagen fiber characteristics in human bone healing, Oral Surg., oral Med., and oral Path. 17: 785, 1964.

[10] Окамото, T.: Estudo histoquímico da reatividade do tecido conjuntivo alveolar após extraçõse dentais, Tese de Doutoramento. Faculdade de Odontologia de Araçatuba, 1964.

[11] Singh, R. F. and UdupA, K. N.: Isotopic tracer studies on the effect of anabolic hormones in healing of fractures, Ind. J. Med. Res. 52: 1, 1964.

[12] Watts, G. T., BdDdeley, M. R., Wellings, R., and Evans, J.: The nature of wound healing: experimental tensile strength studies with deca-durabolin and $S^{35}$, Ann. of Surg. 162: 109, 1965.

[13] Lassila, V. ja Stauffer, A.: Poistohaavan paranemisesta ja alveolilisakkeen muutoksista erilaisten hampaanpoistojen jalkeen, Svom Hammaslark Toim. 62: 223, 1964.

[14] Morse, A.: Formic acid-sodium citrate decalcification and butyl alcohol dehydration of teeth and bone for sectioning in paraffin, J. dent. Res. 24: 143, 1945.

[15] Bowness, J. M.: Calcium binding by chondroitin sulfate associated with collagen, Miochem. Miophys. Acta. 58: 134, 19h2. 